\title{
Jakość i warunki życia w Siechnicach - badanie społeczne
}

\section{Milena Stettner}

\author{
Katedra Urbanistyki i Procesów Osadniczych, Wydział Architektury, Politechnika Wrocławska, \\ e-mail:milena.stettner@pwr.edu.pl,milena.stettner@gmail.com
}

Streszczenie: Jakość życia w mieście mierzona jest przez wiele różnorodnych czynników wpływających na jej odbiór. Połączenie uwarunkowań, zmiany stylu oraz oczekiwań wobec poziomu życia oddziałuje na opinię mieszkańców wobec jakości ich życia w środowisku miasta. W artykule przedstawiono wyniki badań ankietowych w Siechnicach pt. „Jakość i warunki życia w mieście” przeprowadzone latem 2016 roku. Zebrane opinie respondentów dostarczyły wielu cennych uwag i skategoryzowały problemy występujące w mieście. Natomiast wnioski z niniejszych badań pozwolą władzą miasta na ocenę ich skuteczności zarządzania i podejmowania poszczególnych decyzji oraz zdefiniują dalsze działania polepszające jakość życia mieszkańców w Siechnicach.

Słowa kluczowe: ankieta, małe miasto, dostępność usług, infrastruktura techniczna.

\section{Wprowadzenie}

Małe miasto to niewielka społeczność, przestrzeń i drobne usługi zapewniające podstawową egzystencję, funkcja zazwyczaj jednorodna i ludzie, którzy bardzo dobrze się znają. Małe miasta w ostatnich latach przeszły dużą transformację, zarówno w sferze gospodarki, jak i społeczno-ekonomicznej. Miasta znajdujące się blisko ośrodków metropolitalnych, tj. Siechnice, w przeciągu minionych 5 lat przeżyły ogromny wzrost nowych inwestycji mieszkaniowych i aktywności gospodarczej, a przez to napływ nowej ludności. [1]

Celem badania było pokazanie jakości i warunków życia panujących w szybko rozwijającym się małym mieście. Podstawowe potrzeby i problemy, które należy rozwiązać to główne elementy ankiety, która została przeprowadzona na próbie 116 osób zamieszkujących Siechnice. Ankietowani zostali wybrani przypadkowo. Teren opracowania to małe miasto posiadające około 6000 mieszkańców, położone niecałe $12 \mathrm{~km}$ od Wrocławia.

Główną metodą badania była ankieta składająca się z 12 pytań, w tym 2 otwartych, 4 pytań rankingowych z oceną od 1 do 5 punktów oraz 6 pytań zamkniętych prostych. Ponadto w kwestionariuszu znalazła się metryczka respondentów. [2, 3] W kontekście badań nad jakością życia w mieście, analizy uwzględniające urbanistyczną problematykę miasta są związane z szerokim spectrum kryteriów tj. dostępność mieszkań, miejsc pracy, rekreacji, bezpieczeństwo, edukacja, kultura, środowisko, infrastruktura techniczna, jakość wody i powietrza, sprawna komunikacja publiczna, stabilność ekonomiczna i społeczna, możliwość partycypacji społecznej oraz współpraca z władzami. Stworzony kwestionariusz ankietowy uwzględniał wszystkie wyżej przytoczone kryteria w zakresie potrzeb i problemów w mieście w podziale na 3 kategorie: rozwój gospodarczy (dostępność miejsc pracy, stabilność ekonomiczna i społeczna), infrastruktura i środowisko naturalne (infrastruktura techniczna, jakość wody i powietrza, sprawna komunikacja publiczna) oraz kwestie społeczne (dostępność mieszkań, bezpieczeństwo, edukacja, kultura, możliwość partycypacji społecznej oraz współpraca z władzami). Ponadto pierwsza część ankiety miała pokazać 
poziom zadowolenia z życia mieszkańców i ich ocenę miasta/gminy w kontekście idealnego środowiska do życia oraz porównania z gminami ościennymi. Podstawowe definicje wykorzystane w badaniu i przytoczone w niniejszym artykule to jakość i warunki życia, które zostaną rozwinięte w dalszej części opracowania.

\section{Jakość życia w mieście}

Jakość życia potocznie jest określana mianem wyznacznika dobrostanu, zadowolenia, szczęścia, czy poczucia satysfakcji z własnego istnienia. Często zamiennie używana z poziomem, warunkami, czy standardem życia. Analiza nad typologią jakości życia, pokazuje, że powszechnie ma ona ubogą definicję, co w naukowej rzeczywistości bardzo prosto można obalić. [4]

Czym jest zatem ,jakość życia”? Na początek, bez wnikliwej analizy, można przytoczyć kilka definicji, które przewijają się w nauce, zarówno socjologii, filozofii, jak i urbanistyce. Jakość życia to:

- „kategoria, którą charakteryzuje duże zróżnicowanie. Z jednej strony może ona obejmować wartości materialne, ale także wartości niematerialne i duchowe. (...) staje się kategorią filozoficzną, która obejmuje czas wolny, warunki ekonomiczne, środowisko nauki, transport i wiele innych czynników z grupy obiektywnych.”, [5]

- „szeroko akceptowalny cel rozwoju społeczeństwa”, [6]

- „termin, który jest dla nas wszystkich pojęciem fundamentalnym. (...) większość naszych wysiłków kierujemy na poprawę lub utrzymanie jakości życia”. [7]

To pokazuje, jak ważnym aspektem życia dla każdego z nas jest określenie ,jakość”, bez znaczenia czy chodzi o jakość produktu, stosunków międzyludzkich, zagospodarowania przestrzeni, czy przedmiotową jakość życia w mieście.

\subsection{Klasyfikacja jakości życia w środowisku miasta}

Po ogólnej analizie terminu ,jakość życia” należy bliżej przyjrzeć się jej kategoryzacji. Na rycinie poniżej zauważamy klasyfikacje, w której występuje 7 typów podziału. (Rys. 1) Przedmiotem artykułu jest jakość życia w mieście i na tym aspekcie postaram się skupić. Biorąc pod uwagę badania społeczne wykonywane w Siechnicach, niewątpliwie najważniejszym kryterium był podział na czynniki obiektywne i subiektywne występujące w mieście i warunkujące jakość życia. Zacznijmy jednak od pierwszej klasyfikacji - wskaźniki wartościujące i niewartościujące jakość życia.

Wartość, czyli ogólna ocena życia, odpowiedź na pytanie „Czy jest Pan(i) zadowolony ze swojego życia?" (pytanie zadane w ankiecie, przyp. autorki), może być pozytywna lub negatywna. Niewartościująca opinia to opis, dlaczego tak naprawdę nie lubimy, bądź lubimy swoje życie i jakie czynniki mają wpływ na naszą odpowiedź.

Kolejnym kryterium podziału jest globalna i ograniczona jakość życia. Na określenie „globalne" składają się trzy sfery: fizyki, psychiki i duchowości człowieka, czyli rozłożenie potrzeb i konieczność kolejności ich zaspokojenia, również w odniesieniu do jakości życia w mieście: w społeczności lokalnej, w domu/mieszkaniu: w rodzinie, jak i do indywiduum. Sfera ograniczona koncentruje się głównie na aspektach duchowych, co nie dotyczy stricte nauki z dziedziny urbanistyki.

Trzecim w kolejności podziałem jest już wcześniej wspomniana klasyfikacja na obiektywną i subiektywną jakość życia. Obiektywna, czyli wszystko to, co występuje w danym środowisku i wpływa na jakość: zbiór elementów, cech, konkretnie zdefiniowanych, tj. szkolnictwo, pomoc społeczna, usługi, rynek pracy, zasoby mieszkaniowe. Obiektywna 
jakość życia jest bardzo zbliżona do definicji „warunków życia”, w języku planistycznym „uwarunkowań, jakie zastajemy w danym mieście, społeczności, co niepodważalnie każdy z nas ocenia tak samo - „zero-jedynkowo”. O wszystkie te elementy środowiska miasta mieszkańcy zostali zapytani w kwestionariuszu badań przedstawionych w niniejszym artykule. Subiektywna jakość życia to indywidualna ocena danego elementu miasta, pod kątem zadowolenia, dobrobytu, czy empatii. Można ją też tłumaczyć jako indywiduum, które składa się na odbiór miasta, złożony z opinii każdego mieszkańca. I tu przechodzimy do kolejnego podziału, jakim jest indywidualna i zbiorowa jakość życia.

Indywidualna jakość życia, czyli wszystkie cechy miasta, zarówno subiektywne, jak i obiektywne, przedstawione przez każdego z ankietowanych, uwarunkowania, jakie zastali w mieście i ocena ich zadowolenia, które po zsumowaniu dają zbiorowy wynik oceny jakości życia w Siechnicach.

Piątą z kolei klasyfikacją, ujętą w diagramie poniżej jest bezpośrednia i pośrednia jakość życia. Bezpośredniość to obraz zaczerpnięty głównie z badań ankietowych, zawierający subiektywne i obiektywne oceny. Pośredniość to obserwacje badacza dotyczące jakości życia, zazwyczaj na podstawie danych statystycznych, wskaźników, które nie pokazują zdania społeczności, zbiorowości, lecz są liczbą określoną przez autora statystyki, bez poznania indywidualności, a nawet całej omawianej społeczności.

Ostatnie dwa podziały to klasyfikacja na zrównoważoną i niezrównoważoną jakość życia oraz aksjologiczną. Nie dotyczą one bezpośrednio badania jakości życia w mieście, dlatego zostaną pominięte w niniejszym opracowaniu. [4]

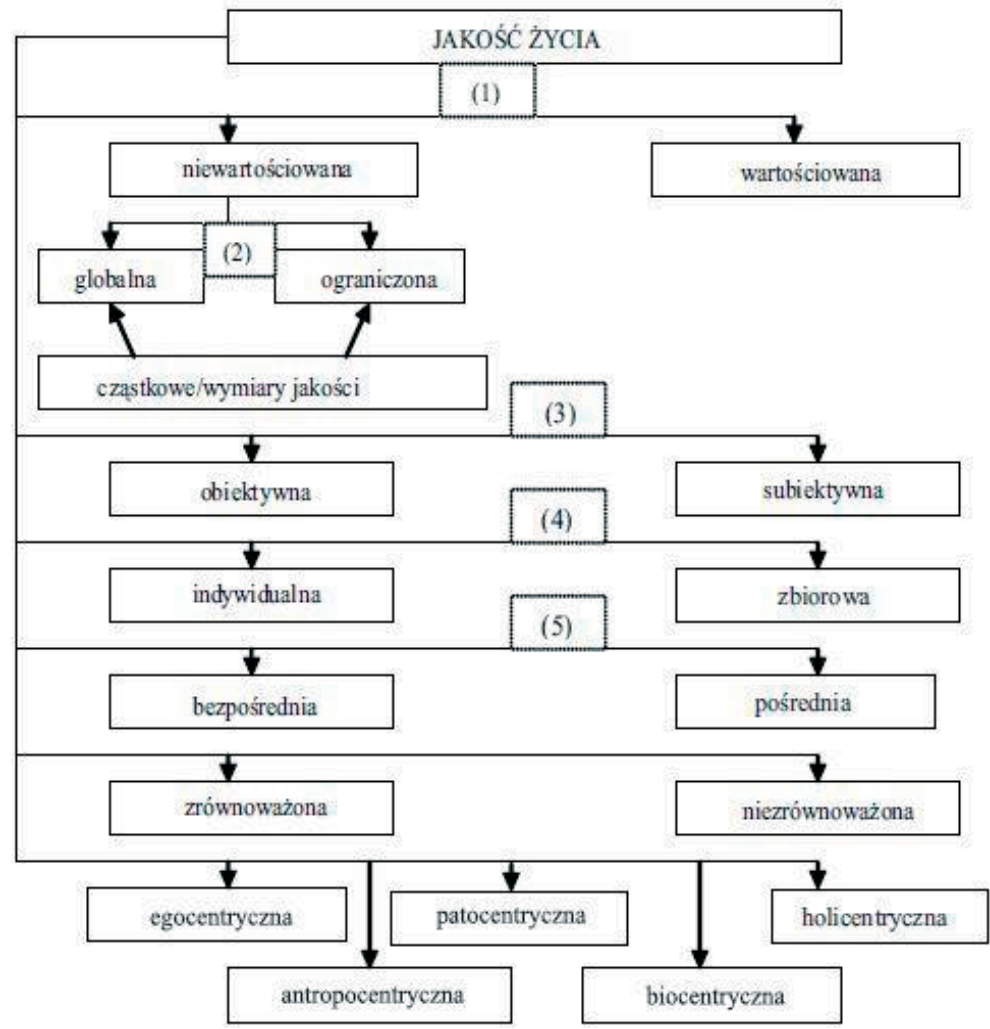

Rys. 1. Klasyfikacja jakości życia, źródło: [4] 
Jakość życia można rozpatrywać na 7 różnych typów jej pomiaru. W mieście zauważa się 5 klasyfikacji jakości życia, które wynikają z obiektywnego stanu posiadania danych warunków, próby zmiany oraz oczekiwań mieszkańców, co do poziomu życia. (Rys. 2)

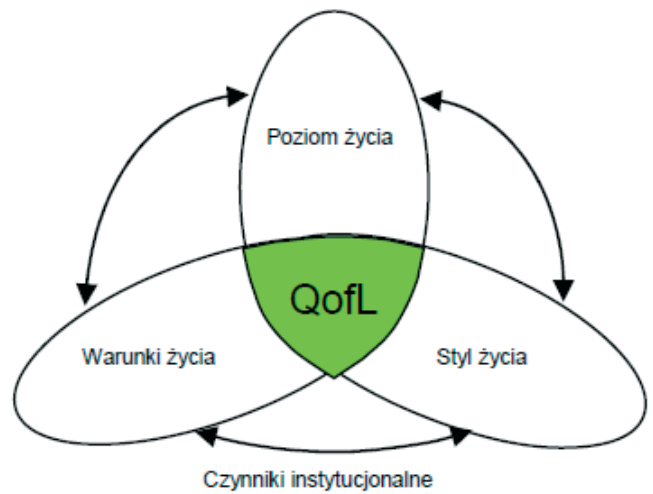

Rys. 2. Jakość życia jako system, źródło: [8]

Kombinacja trzech czynników, tj. warunki życia - uwarunkowania w mieście, styl życia, czyli próba zmiany oraz oczekiwany poziom życia, to wszystko wpływa na ocenę, zarówno obiektywną, jak i subiektywną każdego z mieszkańców. Poprawa warunków panujących w Siechnicach na przełomie ostatnich 5 lat, zmiana funkcji miasta, a przez to stylu życia mieszkańców, udoskonala poziom życia, a co za tym idzie opinię o jakości. [7]

\subsection{Aspekty jakości życia a zarządzanie miastem}

Aspekty pomiaru, odczuwania jakości życia w mieście, wynikają z uwarunkowań przestrzennych, społecznych i ekonomicznych, na które w środowisku miasta, ogromny wpływ mają władze jednostek samorządu terytorialnego. To one kształtują naszą przestrzeń i poziom życia społeczeństwa jako ogółu, poprzez podejmowanie decyzji o formułowaniu celu publicznego. Zarządzanie miastem to istotny czynnik determinujący zadowolenie, radość i satysfakcje z życia w obrębie miasta. Liczne badania pokazują, że działania naprawcze i udoskonalające, tj. rewitalizacja, modernizacja, nowe inwestycje, działania społeczne wpływają na zwiększenie odczuwania tożsamości z miastem i poczucie przynależności, czyli zadowolenia $\mathrm{z}$ faktu bycia mieszkańcem danego miasta. Wybory do samorządu gminy, miasta to ogromna odpowiedzialność na jego mieszkańcach i oddziaływanie pośrednie na poziom życia w mieście przez najbliższe 4 lata. Cele rozwoju jakie wyznaczają kandydaci w wyborach stanowią później o skuteczności w zarządzaniu miastem, a co za tym idzie też na poczucie jakości życia w mieście. Wyniki badań w Siechnicach przedstawione poniżej stanowią także o skuteczności zarządzania miastem przez jego władze, dlatego są tak istotne dla samych mieszkańców, ale również dla jego zwierzchników. [5]

\section{Diagnoza społeczna - warunki i jakość życia w Siechnicach (wyniki badań ankietowych)}

Siechnice to małe miasto leżące we wschodniej części województwa dolnośląskiego, zaledwie 12 km od Wrocławia. Prawa miejskie uzyskało w 1997 r., w 2010 r. stało się siedzibą gminy miejsko-wiejskiej. Od 1989 r. w mieście powstało ponad 17 nowych inwe- 
stycji kubaturowych, wpływających na rozwój sektora gospodarki, zasobów mieszkaniowych oraz warunków i jakości życia, poprzez dostęp do szerokiej gamy usług, wyposażenia mieszkań w instalacje techniczno-sanitarne i poprawę estetyki miasteczka. Bliskość do ośrodka metropolitalnego i ruchu tranzytowego wpłynął na intensywnie rozwijający się rynek nieruchomości mieszkaniowych. Deweloperzy coraz chętniej budują w Siechnicach swoje inwestycje, co powoduje wzrost liczby mieszkańców, szczególnie w grupie ekonomicznej produkcyjnej i przedprodukcyjnej. Mieszkańcy są lepiej nastawieni na zmiany i chętniej podejmują czynności w sferze rozrywki, usług, przedsiębiorczości i działań na korzyść miasta, co pokazują również badania ankietowe przedstawione poniżej.

Kwestionariusz ankietowy wykorzystany w niniejszym badaniu został opracowany z podziałem na 3 podstawowe elementy: charakterystykę respondentów, opinię/ocenę miasta wg mieszkańców i poziom ich zadowolenia z życia w mieście, oraz najważniejszy trzeci element ankiety ocenę/klasyfikację potrzeb i problemów występujących w mieście, uwzględniających wszystkie przytoczone kryteria w pierwszej części artykułu.

\subsection{Charakterystyka respondentów}

W badaniu ankietowym wzięło udział 116 osób. W większości były to kobiety (Rys. 3), w wieku 25-34 lata (Rys. 4), z wykształceniem wyższym (Rys. 5), aktywne na rynku zawodowym (Rys. 6). Ze względu na charakterystykę mieszkańców Siechnic, badanie przyjęto z dużym entuzjazmem, zarówno wśród samych respondentów, jak i w siedzibie władz miasta. Ankieta przebiegała bardzo płynnie i cieszyła się dużym zainteresowaniem. Mieszkańcy oprócz uczestnictwa w badaniu, chętnie opowiadali o swoim mieście oraz wykazywali aktywność w rozmowach nad przyszłością miasteczka.

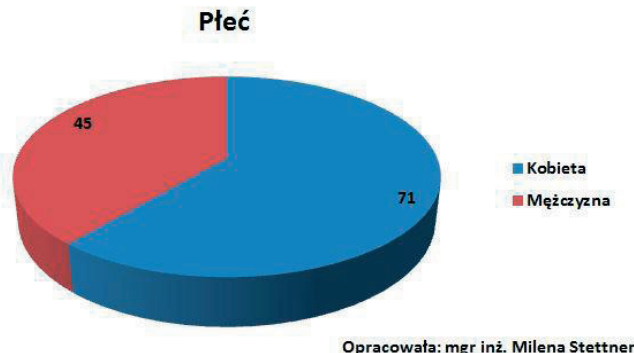

Rys. 3. Płeć respondentów

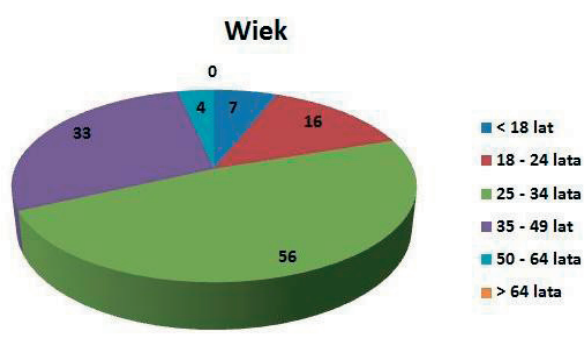

Opracowała: $\mathrm{mgr}$ inż. Milena Stettner

Rys. 4. Wiek respondentów

Wykształcenie

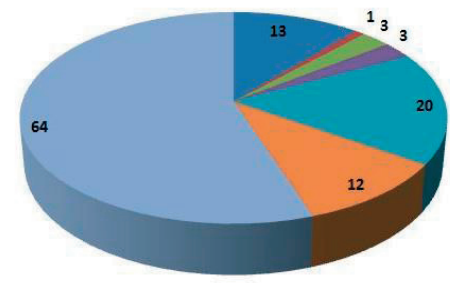

Opracowała: mgr inż. Milena Stettne
అ Uczeń/student

a Podstawowe

m Gimnazjalne

Zawodowe

- Średnie

a Pomaturalne

Wyisze

Aktywność zawodowa

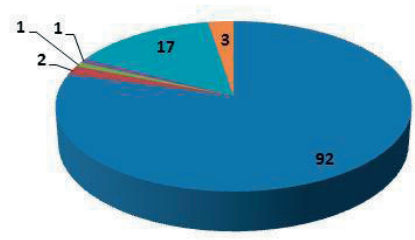

Opracowała: mgr inż. Milena Stettner

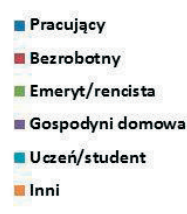

Eracujący

Emeryt/rencista

- Uczeń/student

inn

Rys. 5. Wykształcenie respondentów

Rys. 6. Aktywność zawodowa respondentów 


\section{2. „Mój piękny habitat” - ocena miasta wg mieszkańców}

Ocena to subiektywne, indywidualne zdanie każdego z respondentów, które w połączeniu przedstawia obraz małego miasta w opinii całej społeczności. W ankiecie, oprócz zaopiniowania istotnych problemów i potrzeb w mieście, mieszkańcy oceniali swoje zadowolenie z życia i z mieszkania w Siechnicach. Około 85\% (100 osób) na pytanie „Czy jest Pan(i) zadowolony(a) ze swojego życia?” odpowiedziało „tak” lub „raczej tak”. (Rys. 7) Ponad 80\% (98 osób) ankietowanych jest zadowolonych z faktu, że mieszka w Siechnicach. (Rys. 8) To potwierdza duży entuzjazm w zaangażowaniu w ankietę i propozycje udoskonalenia jakości życia.

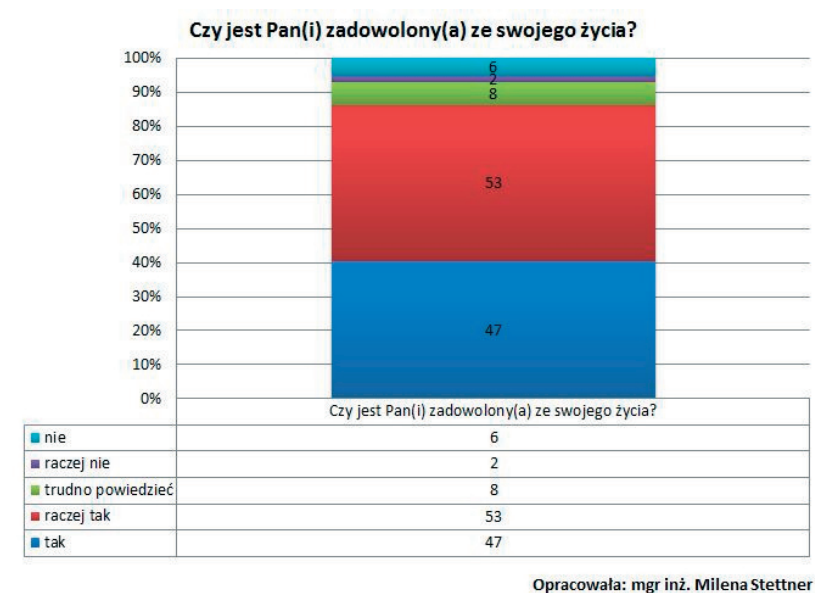

Rys. 7. Zadowolenie ze swojego życia ankietowanych

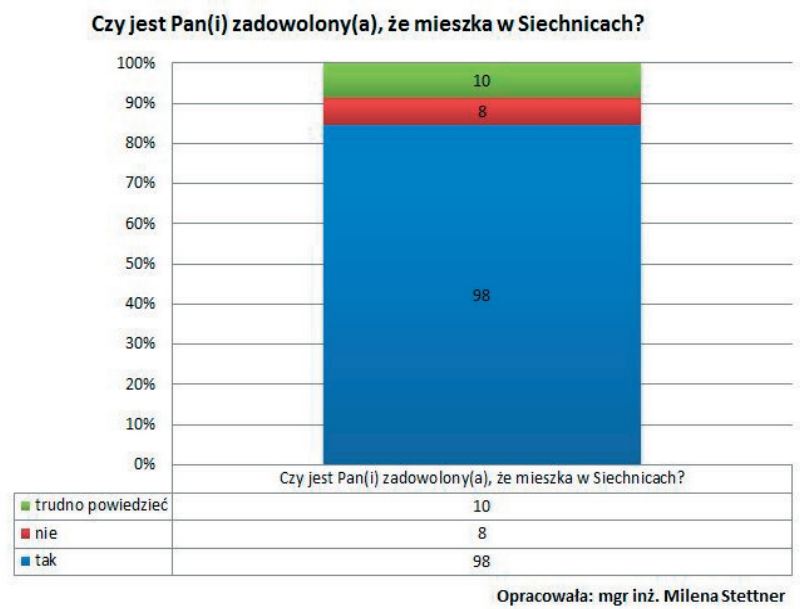

Rys. 8. Zadowolenie z życia w Siechnicach ankietowanych

Ponad 60\% wszystkich respondentów, biorących udział w ankiecie, mieszka w Siechnicach poniżej 10 lat, z rozkładem na 34 osoby zamieszkujące poniżej 3 lat i 40 osób od 3 do 10 lat. (Rys. 9) Zaledwie około 25\% (31 osób) wyprowadziłaby się z miasta, gdyby istniała taka możliwość. (Rys. 10) 


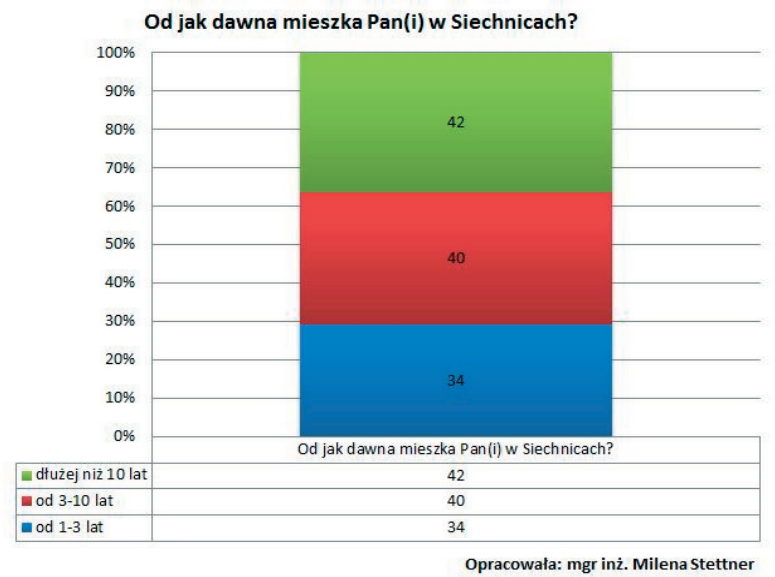

Rys. 9. Długość zamieszkiwania w Siechnicach

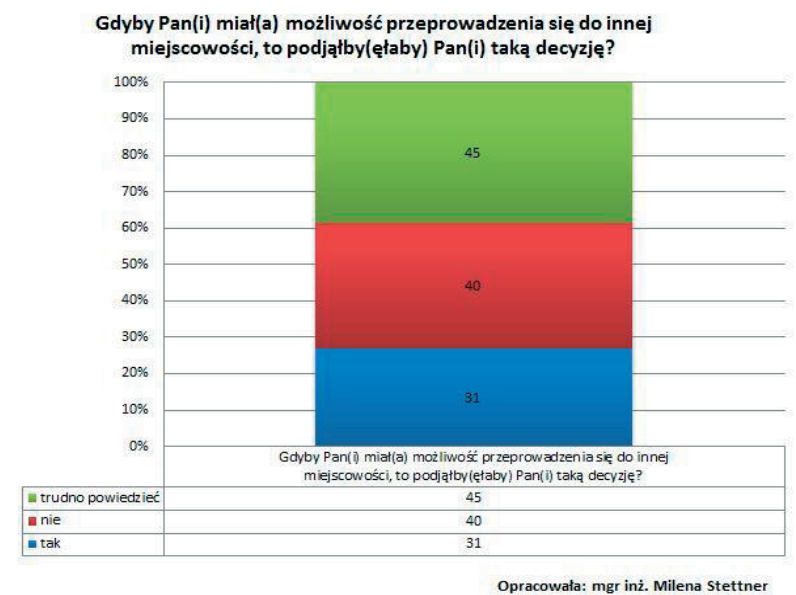

Rys. 10. Chęć wyprowadzenia się do innego miasta

W 2007 r. autorka książki „Siechnice. Rodowód miasta.” przeprowadziła podobne badania na próbie 75 mieszkańców Siechnic, w których również zadała pytania dotyczące chęci wyprowadzenia się do innego miasta. Wynik jest porównywalny do obecnego, około $25 \%$ (20 osób) wyraża chęć wyprowadzki. (Rys. 11) Pobudki do tej decyzji mogą być różne, zazwyczaj są to kwestie finansowe, rodzinne lub zawodowe. W przeciągu ostatnich 10 lat w mieście wiele się zmieniło, powstały nowe ośrodki w Specjalnej Strefie Ekonomicznej, a co za tym idzie nowe miejsca pracy, nowe inwestycje deweloperskie, przez co jakość życia pod względem mieszkaniowym również wzrosła, co niestety nie wpłynęło na zmniejszenie procentowej ilości chętnych do zmiany miejsca zamieszkania. Nadal waha się ona na poziomie $25 \%$. [9]

Odczuwalny poziom rozwoju na tle sąsiadujących gmin jest w ocenie większości mieszkańców wyższy (55 osób) lub porównywalny (44 osób). Zaledwie 8 osób uważa, że poziom życia w ich gminie jest niższy od poziomu w innych jednostkach samorządu terytorialnego. (Rys. 12) Ponad 80\% (95 osób) ankietowanych uważa, że warunki życia w Siechnicach przez ostatnie 5 lat „poprawiły się” lub ,zdecydowanie się poprawiły”, co potwierdza rezultat odpowiedzi na pytanie dotyczące ich zadowolenie z życia w miasteczku. 
9 osób stwierdziła, że warunki życia „pogorszyły się” lub „zdecydowanie się pogorszyły”, co jest z pewnością tożsame $\mathrm{z}$ odpowiedzią na poprzednie pytanie poświęcone poziomowi rozwoju na tle innych gmin. (Rys. 13)

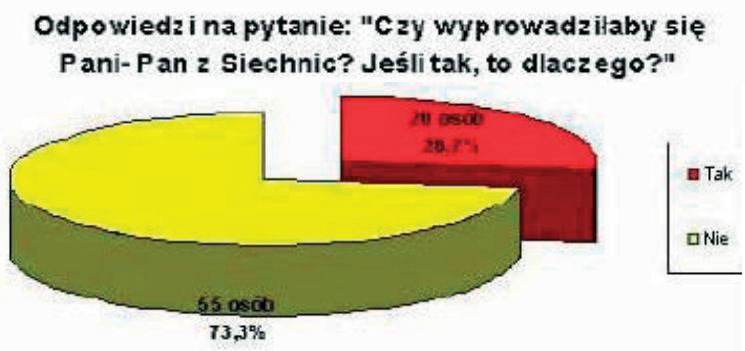

Rys. 11. Chęć wyprowadzenia się z Siechnic, źródło: [9]

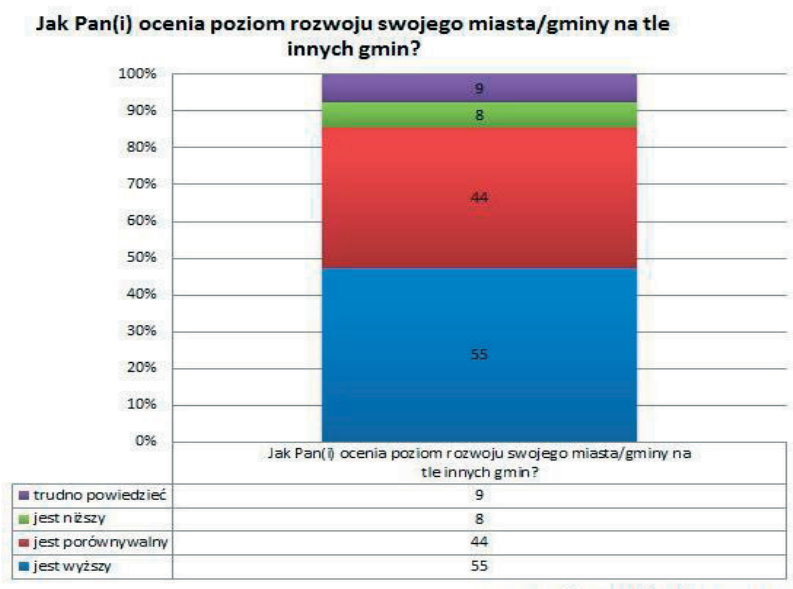

Opracowała: mgr inż. Milena Stettner

Rys. 12. Poziom rozwoju wg ankietowanych

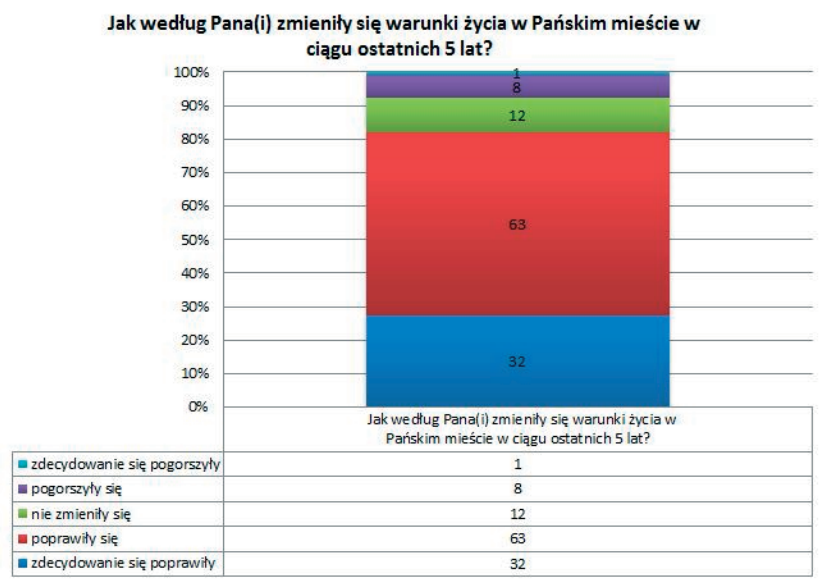

Opracowała: mgr inż. Milena Stettner

Rys. 13. Zmiany warunków życia w ostatnich 5 latach 
Oprócz oceny warunków życia w mieście, mieszkańcy odpowiedzieli na pytania otwarte: „Proszę napisać co według Pana(i) szczególnie się poprawiło w mieście?” (Tab. 1) i „Proszę napisać co według Pana(i) szczególnie się pogorszyło w mieście?” (Tab. 2). Większość odpowiedzi powtarzała się w ankietach mieszkańców, szczególnie dotycząca zagospodarowania terenu: drogi, chodniki, ścieżki rowerowe, oświetlenie, zieleń towarzysząca, powstanie placów, miejsc spotkań, targowiska i poprawy estetyki miasta. Część mieszkańców zwróciła dużą uwagę na powiększająca się bazę usług, sportu, rekreacji, mieszkań, miejsc pracy i szkolnictwa.

Tabela 1. Aspekty życia poprawiające warunki panujące w mieście

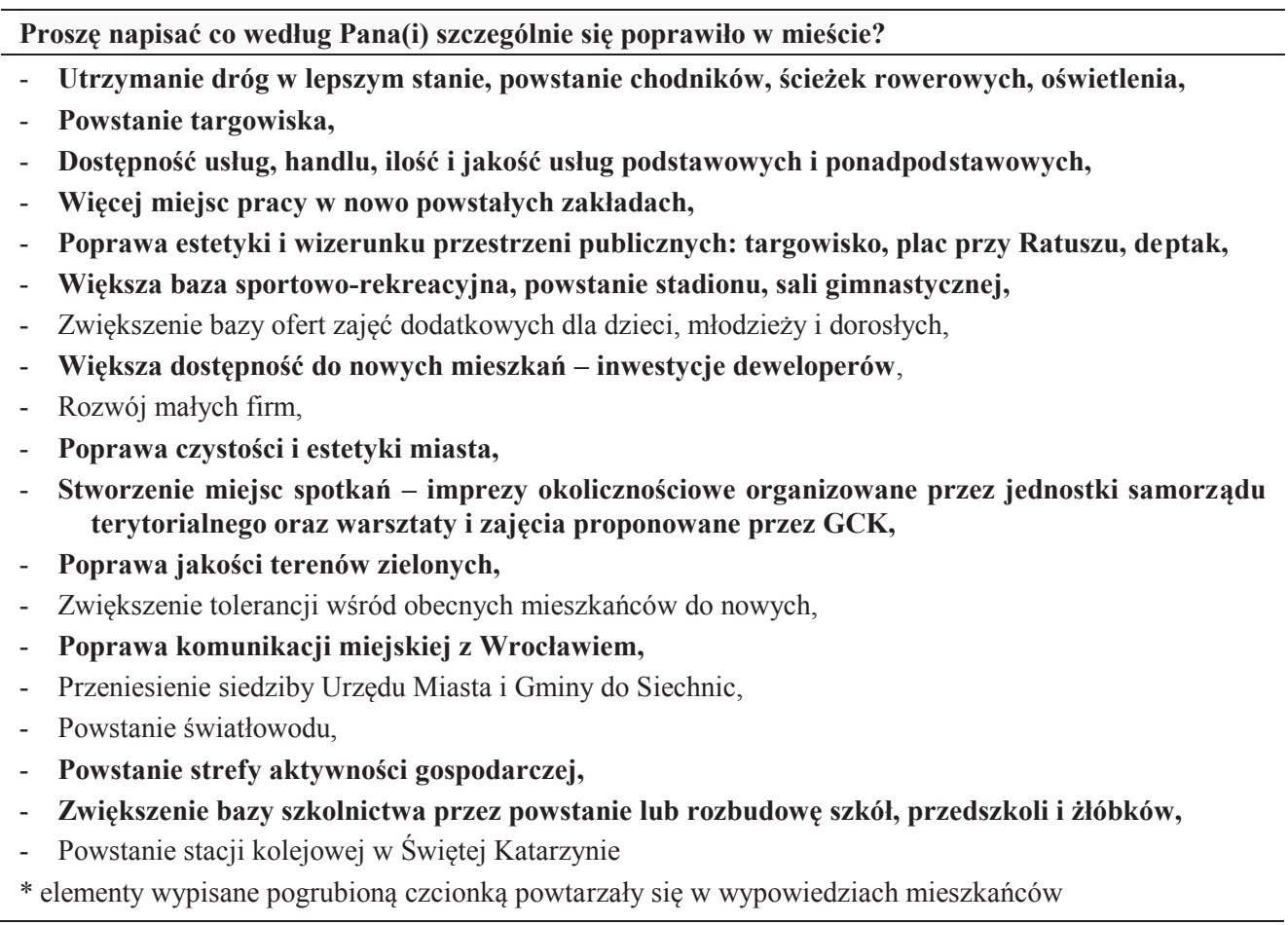

Wzrost terenów zabudowanych, powiększający wcześniej wspomnianą bazę usług i mieszkalnictwa, według niektórych mieszkańców pogarsza jakość życia, przez zmniejszającą się ilość zieleni, niewystarczającą wydajność kanalizacji, wodociągów, służby zdrowia oraz oferowanych usług na tak szybko wzrastającą liczbę ludności. Oprócz wyżej wspomnianych problemów szybko rozwijającego się miasta trzeba również dołożyć spotęgowanie przestępczości, kradzieży, hałasu i słabej przepustowości dróg publicznych i komfortu w komunikacji miejskiej. 
Tabela 2. Aspekty życia pogarszające warunki panujące w mieście

Proszę napisać co według Pana(i) szczególnie się pogorszyło w mieście?

- Mniejsza ilość zieleni na rzecz urbanizacji,

- Brzydki zapach z oczyszczalni ścieków,

- Poziom nauczania w Szkole Podstawowej, duża rotacja nauczycieli w nauczaniu wczesnoszkolnym, stan szkoły - toalety,

- Wzrost liczby mieszkańców - niedostosowanie komunikacji, zarówno miejskiej do Wroclawia, jak i przepustowości głównych dróg - ciągłe korki,

- Slużba zdrowia, brak przychodni zdrowia „z prawdziwego zdarzenia”,

- Bezpieczeństwo publiczne, częste kradzieże,

- Duży ruch samochodów - ruch tranzytowy przez miasto,

- Powstawanie zabudowy mieszkaniowej niewspółmiernie do wydolności infrastruktury m.in. wodociągowej - slabe ciśnienie wody, jakość wody; kanalizacyjnej; usług podstawowych np. piekarni,

- Mało baza atrakcji dla młodych,

- Gęstość zabudowy - brak wystarczającej ilości miejsc parkingowych, male zaplecze zieleni, brak miejsc w szkołach, przedszkolach, żłobkach, przychodniach zdrowia,

- Małe zaplecze usług gastronomicznych, handlu - odzież, obuwie,

- Kontakt z sąsiadami - dużo nowych mieszkańców,

- Poziom rozwoju kultury,

- Wzrost ilości dzieci w mieście - za mało placów zabaw, miejsc w żłobkach, zaplecza dla dzieci, brak miejsc spotkań dla matek $\mathrm{z}$ dziećmi,

- Poziom halasu,

- Jakość powietrza - większe zapylenie i kurz

* elementy wypisane pogrubioną czcionką powtarzały się w wypowiedziach mieszkańców

\subsection{Urbanistyczna problematyka miasta - potrzeby i problemy wg kryteriów oceny jakości życia w mieście}

\subsubsection{Ocena zaspokojenia potrzeb w mieście wg mieszkańców}

Potrzeby to wszystko to, co niezbędne do prawidłowego, optymalnego, satysfakcjonującego oraz komfortowego życia, zarówno w przestrzeni, jak i w miejscowej społeczności. Kolejnym elementem ankiety była ocena zaspokojenia potrzeb w mieście, tych podstawowych i tych podnoszących jakość życia. Ankietowani mieli do dyspozycji punktową możliwość oceny od 1 do 5 każdego z elementów podanych w kwestionariuszu, gdzie 1 oznaczało najniższą ocenę, czyli praktyczny brak możliwości zaspokojenia danej potrzeby, a 5 najwyższą notę. Zaledwie jeden z aspektów „dostępność mieszkań komunalnych” otrzymał notę poniżej średniej $(<2,50)$. W ogólnym rozrachunku miasto wypadło zadowalająco, jednak elementy, które otrzymały ocenę poniżej dostatecznej $(3,00)$, wymagają udoskonalenia. Mieszkania komunalne to nie jedyny istotny czynnik, który otrzymał ocenę poniżej 3,00. Potrzeby kultury, ochrony zdrowia, pomocy społecznej, rozwoju zawodowego, znalezienia pracy i dostępności sklepów innych niż spożywcze są ważnymi dziedzinami życia, które potrzebują wsparcia w prawidłowym funkcjonowaniu i zaspokajaniu potrzeb mieszkańców. Niektóre z nich tj. ochrona zdrowia i potrzeby kultury zostały wspomniane we wcześniejszej części ankiety, dotyczącej elementów, które pogorszyły się w mieście. To potwierdza o słuszności podejmowania działań w tej sferze życia mieszkańców. Najwyższą notę otrzymała dostępność usług (tj. fryzjerskie, kosmetyczne) oraz dostępność mediów (Internet, telewizja). (Rys. 14) 


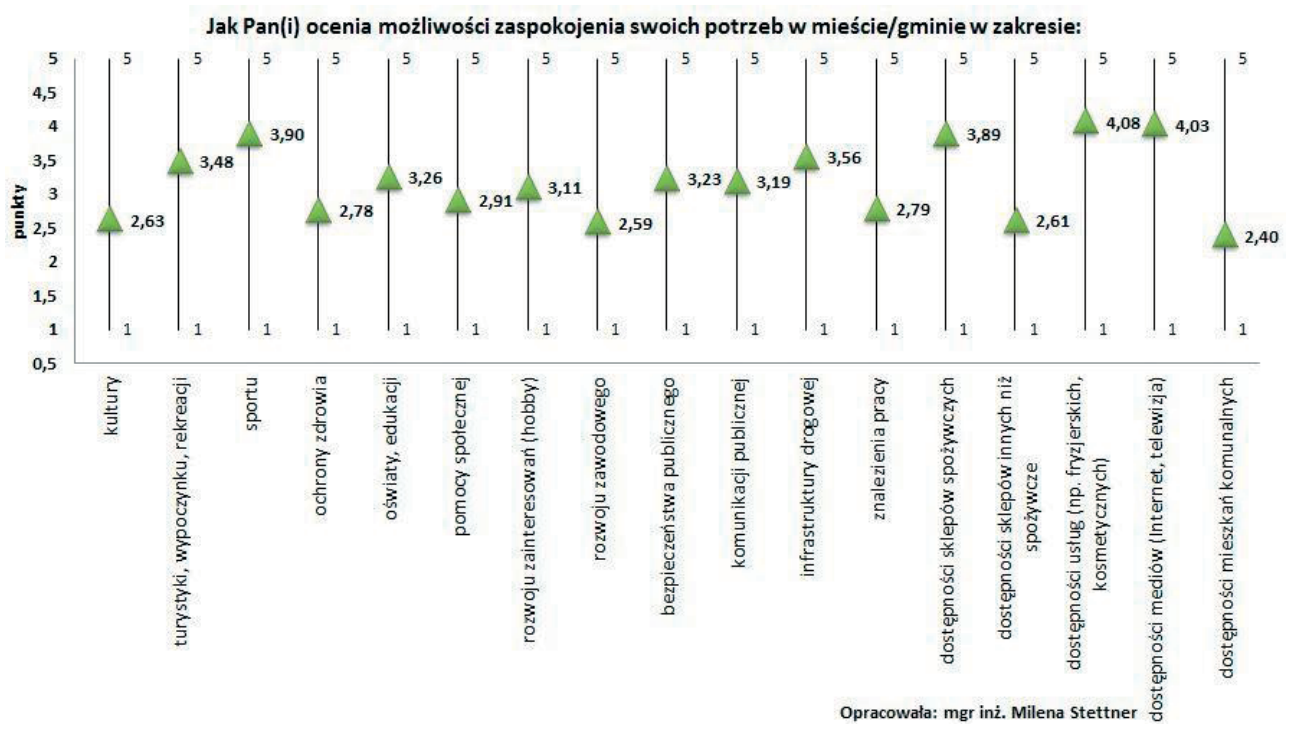

Rys. 14. Ocena zaspokojenia potrzeb mieszkańców Siechnic

\subsubsection{Ocena problemów w mieście wg mieszkańców}

Problemy występujące w mieście są ważne dla mieszkańców, dlatego w ankiecie pytanie dotyczące ich klasyfikacji, zostało najbardziej rozwinięte z podziałem na trzy dziedziny: problemy w zakresie rozwoju gospodarczego, infrastruktury i środowiska naturalnego oraz kwestii społecznych. Podobnie jak w poprzednim pytaniu respondenci mieli do dyspozycji ocenę od 1 do 5, gdzie 1 oznaczało mało ważny problem do rozwiązania oraz 5, problem bardzo ważny, wymagający natychmiastowej ingerencji. W zakresie rozwoju gospodarczego respondenci za najistotniejsze uznali wspieranie przedsiębiorczości mieszkańców. Małe miasto powinno rozwijać sektor małych firm i napędzać gospodarkę miasta. To poprawi nie tylko kondycję gospodarki, miasta, ale również komfort życia mieszkańców, poprzez powstawanie szeregu drobnych usług zaspokajających potrzeby społeczności lokalnej. (Rys. 15)

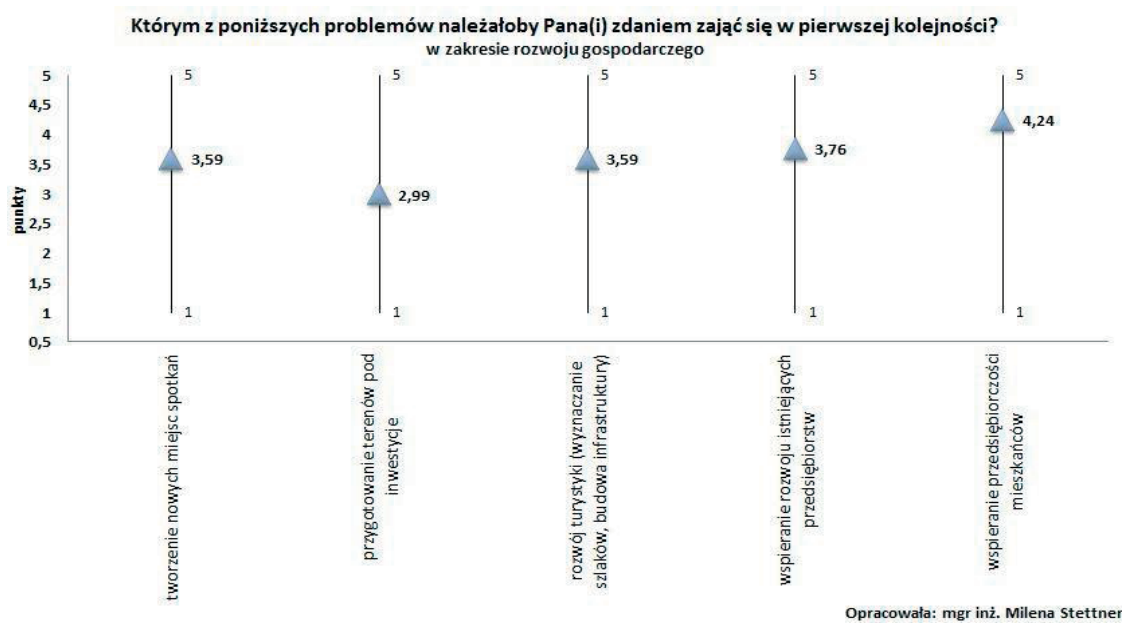

Rys. 15. Problemy w zakresie rozwoju gospodarczego występujące w Siechnicach 
Infrastruktura techniczna to dziedzina zapewniająca podstawowe potrzeby mieszkańców, tj. woda, kanalizacja, energia elektryczna, oczyszczanie ścieków. Na początku ankiety, w pytaniu otwartym mieszkańcy zwracali uwagę na niewydolność kanalizacji, wodociągów i oczyszczalni ścieków, ze względu na szybki wzrost mieszkańców. W pytaniu dotyczącym problemów, te aspekty powtarzają się. Za najistotniejsze właściwości, konieczne do rozwiązania, mieszkańcy uznali poprawę w zakresie zaopatrzenia w wodę, modernizację i rozbudowę sieci wodnokanalizacyjnej i deszczowej oraz poprawę systemu gospodarowania odpadami. (Rys. 16)

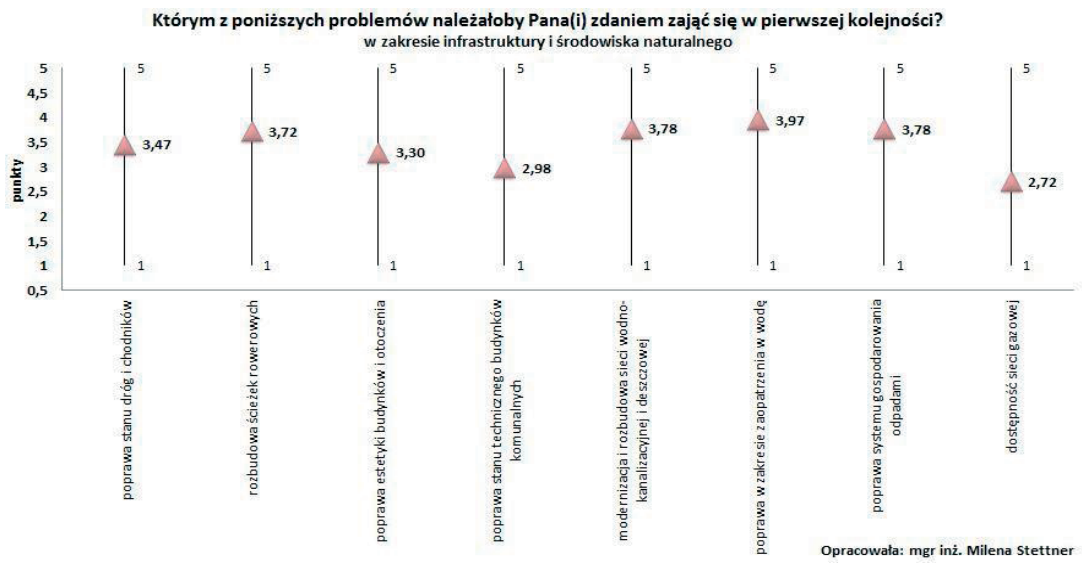

Rys. 16. Problemy w zakresie infrastruktury i środowiska naturalnego występujące w Siechnicach

Społeczeństwo Siechnic to młodzi, zróżnicowani, zazwyczaj napływający z Wrocławia, aktywni zawodowo i posiadający dzieci mieszkańcy, którzy potrzebują przestrzeni do aktywnego odpoczynku oraz miejsc rozrywki dla dzieci. W pierwszej kolejności wg mieszkańców powinno się rozwiązać problemy tj. rozwój infrastruktury sportowo-rekreacyjnej (np. budowa basenu) i dostępność do opieki zdrowotnej, o której już większość ankietowanych wspominała we wcześniejszej części kwestionariusza. (Rys. 17)

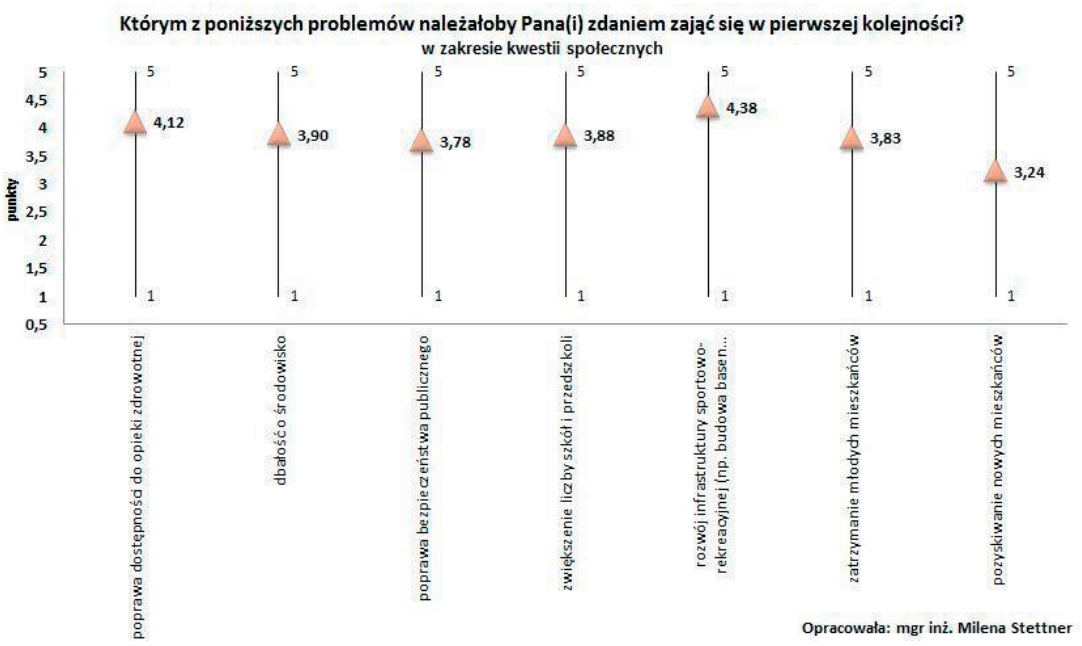

Rys. 17. Problemy w zakresie kwestii społecznych występujące w Siechnicach 


\section{Podsumowanie}

Z zaprezentowanych wyników badań wynika, że mieszkańcy Siechnic są zadowoleni z kształtowania ich środowiska życia przez władze miasta oraz warunków panujących w miasteczku, które obiektywnie wpływają na jakość ich życia. Ogólne poczucie zadowolenia i pozytywna opinia o Siechnicach, potęguje wzrost jej stałych mieszkańców, na co niestety miasto jeszcze nie jest do końca przygotowane. Podstawowe warunki, tj. infrastruktura techniczno-sanitarna i przepustowość dróg to główne elementy wymagające naprawy i dostosowania do szybkiego wzrostu ludności. Same inwestycje mieszkaniowe i w sferze aktywności gospodarczej bez zaplecza przestrzeni do odpoczynku, usług itp. nie zapewnią podstawowych potrzeb mieszkańców i w miarę upływu czasu bez podjęcia jakichkolwiek działań mogą wpłynąć na pogorszenie wyników niniejszych badań, czyli ogólnej oceny miasta. Jednak przez wzgląd na duże zainteresowanie badaniami władz miasta jako badacz jestem spokojna i usatysfakcjonowana stanem i podejściem zarządzających Siechnicami i ich nastawieniem do poprawy poziomu życia w mieście. Głos mieszkańców w badaniu był elementem partycypacji społecznej w podejmowaniu działań i kategoryzacji problemów w mieście. Zaprezentowane w niniejszym artykule wnioski pozwolą na zwartościowanie i klasyfikacje poszczególnych działań w odpowiedniej kolejności ich podejmowania.

\section{Literatura}

1. Stettner M. Wplyw zmian w zagospodarowaniu przestrzennym matych miast po 1989 roku urbanistyczna strukturę miasta. Problemy Rozwoju Miast Kwartalnik Instytutu Rozwoju Miast, II/2015, Kraków 2015, s. 11-24.

2. Pawłowska K. (red.) Zanim wybuchnie konflikt. Idea i metody partycypacji społecznej w ochronie krajobrazu i ksztaltowaniu przestrzeni (tom A: Dlaczego?). Fundacja Partnerstwo dla Środowiska, Kraków 2010.

3. Pawłowska K. (red.) Zanim wybuchnie konflikt. Idea i metody partycypacji społecznej w ochronie krajobrazu i ksztaltowaniu przestrzeni (tom B: Jak?). Fundacja Partnerstwo dla Środowiska, Kraków 2010.

4. Borys T. Gospodarka a Środowisko, [w:] Propozycja siedmiu typologii jakości życia, (ed. Matysiak A.). Prace naukowe Akademii Ekonomicznej we Wrocławiu nr 22, Wrocław 2008, s. 120-129.

5. Szołtysek J., Otręba R. Zarządzanie miastem i jego wpływ na jakość życia mieszkańców miast województwa śląskiego - doniesienie badawcze. Problemy Rozwoju Miast Kwartalnik Instytutu Rozwoju Miast, II/2015, Kraków 2015, s. 37-42.

6. Czepkiewicz M., Jankowski P. Analizy przestrzenne $w$ badaniach nad jakościa życia $w$ miastach. Ruch prawniczy, ekonomiczny i socjologiczny, I/2015, Poznań 2015.

7. Owsiński J. W., Tarchalski T. Pomiar jakości życia. Uwagi na marginesie pewnego rankingu. Zeszyty Naukowe Wydziału Informatycznych Technik Zarządzania Wyższej Szkoły Informatyki Stosowanej i Zarządzania „Współczesne Problemy Zarządzania”, I/2008, Warszawa 2008.

8. Sienkiewicz P, Świeboda H. Modele ewaluacji jakości życia w badaniach systemowych, [w:] Badania operacyjne i systemowe: decyzje, gospodarka, kapitat ludzki i jakość. Badania systemowe. (ed. Owsiński J.W., Nahorski Z., Szapiro T.). 64. IBS PAN, Warszawa 2008.

9. Gonda-Soroczyńska E. Siechnice. Rodowód miasta. Wydawnictwo Uniwersytetu Przyrodniczego, Wrocław 2007. 


\title{
The quality and conditions of life in Siechnice - social research
}

\section{Milena Stettner}

Katedra Urbanistyki i Procesów Osadniczych, Wydział Architektury, Politechnika Wrocławska, e-mail:milena.stettner@pwr.edu.pl

\begin{abstract}
Quality of life in the town is measured by a variety of factors influencing its reception. The combination of conditions, changes in style and expectations for the quality of life affects the opinion of the residents to their quality of life in a town environment. The article presents the results of surveys in Siechnice titled "The quality and conditions of life in the town" conducted in summer 2016. The submissions of the respondents have provided a lot of valuable comments and classified problems in the town. While the conclusions of this study will help authority of the town to assess the effectiveness of management and making individual decisions and define further actions for improving the quality of life of residents in Siechnice.
\end{abstract}

Keywords: survey, small town, availability of services, technical infrastructure. 